\title{
Predicting spawning date of nyale worms (Eunicidae, Polychaeta) in the southern coast of Lombok Island, Indonesia
}

\author{
IMAM BACHTIAR ${ }^{1,2, v}$, NAILA TASLIMAH BACHTIAR ${ }^{3}$ \\ ${ }^{1}$ Department of Science Education, Faculty of Teacher Training and Education, Universitas Mataram. Jl. Majapahit 62, Mataram 83125, West Nusa \\ Tenggara, Indonesia. Tel./fax. +62-370-623873. ”email:imambachtiar@unram.ac.id \\ ${ }^{2}$ Program of Science Education, Graduate Program, Universitas Mataram. Jl. Majapahit 62 Mataram 83125, West Nusa Tenggara, Indonesia \\ ${ }^{3}$ Department of Aquaculture, Faculty of Fisheries and Marine Science, Universitas Brawijaya. Jl. MT. Haryono 169, Malang 65145, East Java, Indonesia
}

Manuscript received: 6 February 2019. Revision accepted: 11 March 2019.

\begin{abstract}
Bachtiar I, Bachtiar NT. 2019. Predicting spawning date of nyale worms (Eunicidae, Polychaeta) in the southern coast of Lombok Island, Indonesia. Biodiversitas 20: 971-977. Spawning of marine nyale worms has been an important component of Sasak tradition of Bau Nyale (fishing nyale) for centuries and a tourism icon of the District of Lombok Tengah since the 1990s. Nyale is a mixture of epitokies of 3-5 species of Polychaeta worms (mostly Palola spp.) for reproduction. At present, prediction of spawning date of the nyale worms is carried out traditionally that might not satisfy demand of tourism market. The present study is to develop a scientific-based method for predicting date of nyale worms spawning or nyale swarming. Since available data are scarce, development of the method of data collection mainly uses analogy from polychaetes and other invertebrate reproduction patterns and any available information from traditional customs. Three hypotheses were developed to generate prediction for 100 years, from 2000 to 2100 , and then these prediction dates were verified using available data before 2018. In the past 9 years, there are two mismatches between scientific and traditional predictions, i.e., 2015 and 2017 spawnings, in favor of the new prediction method. The new scientific prediction method provides more objective and accurate date of nyale worm spawning than the traditional method. The present prediction also shows that split spawning dates, February and March, do not come to pass every year, as traditional nyale fishers generally believe them. It is also found that nyale worms are consistently using international lunar calendar for its spawning date, instead of local and national lunar calendars. This study provided the first scientific nyale swarming prediction in Lombok to complement existing traditional prediction. The prediction is very useful to promote the biggest annual traditional festival in Lombok for international visitors.
\end{abstract}

Keywords: Bau nyale, cultural, Polychaete, swarming, tourism

\section{INTRODUCTION}

Prediction of polychaete worms spawning, sometimes called as swarming, is very much important for Sasak community in Lombok Island. During the spawning night, polychaete worms release their epitokes (or nyale, Sasak) swarming in the water column. The swarming nyale will be naturally fragmented by waves that release sperms and eggs packed inside them into seawater. In the present study, nyale worms are defined as Polychaete worms that produce swarming epitokes during the Bau Nyale (nyale fishing) tradition in Lombok Island. The nyale fishing tradition is carried out throughout a nyale swarming night that occurs once or twice a year.

Nyale worms are not a single species. Nyale worms at least consist of Eunice (Palola) viridis and Lysidice collaris (Jekti et al. 1993), and they are about the same as palolo worms (Eunice viridis, Palola viridis, P. siciliensis) in Samoa (Caspers 1984) and wawo worms (Eunice spp., Palola sp., Lysidice oele) in Ambon (Pamungkas 2015). Coastal people have traditionally utilized these large-body Polychaete worms for ages, but their reproductive cycle has been under examination and prediction of their spawning dates is merely prepared by traditional leaders. Scientific prediction on nyale swarming is not yet available.
Cultural value of Polychaete spawning has been strongly linked to myth and folklore. It has been hundreds of years that coastal community only rely on traditional prediction for determining date of nyale fishing. Along with their experiences on inaccuracy of the traditional prediction, traditional community has also developed local wisdom of elegant defense when traditional prediction failed. They blame the inaccuracy prediction to incomplete natural signs required for nyale swarming. This local wisdom and virtuosity to protect their traditional leader from making charitable mistakes is observed in many communities utilizing swarming worms, including Samoa, Hawaii (Caspers 1984; Mundy and Green 1999) and Sasak (Lombok). In Lombok Island, nyale swarming is no longer merely cultural event, but it is also an important economic asset as tourism attraction.

Absorbing nyale fishing tradition into tourism market gives result in demand to have more accurate prediction on date of nyale swarming. Government promotes the event of nyale fishing festival internationally just after a sacred meeting is run by cultural leaders, Sangkep Beleq. The traditional meeting is to determine the date of nyale swarming, which is usually held in early December. The meeting comes up with the date of nyale swarming on the following year on February-March. Tourism market needs 
beforehand information on the date of swarming, as early as one year. The market also needs more accurate prediction to satisfy visitors. Both demands, however, can hardly be fulfilled by traditional prediction. When this cultural event becomes tourist attraction, however, the elegant defense might no longer be acceptable. There is an urgent need, therefore, to have a scientific prediction. Spawning of nyale worms is biologically an ultimate part of reproduction processes that it should be scientifically predictable.

Reproduction cycle has been predictable in many marine invertebrates. Spawning animals invest high amount of resources with low fertilization opportunity in aquatic environment. Reproductive synchrony is therefore very much important to maximize reproductive output. Such asynchrony may be achieved by using natural cues from annual cycles of temperature (Olive 1980; Willis et al. 1985; Babcock et al. 1986) or photoperiod (Olive 1995) or both of them (Babcock et al. 1994; Olive 1995; Brownstein and Loya 2015), and lunar or tidal cycles (Fong 1993). Coral reproduction in the Great Barrier Reefs has long been accurately predicted to species level and hours of spawning time (Willis et al. 1985; Babcock et al.1986) since it has been known that their spawning date and time are strongly linked with temperature, moon phase, and tidal cycles.

Reproductive patterns of nyale worms annual spawning, however, is less studied. Caspers (1984) has studied patterns of palolo worm spawning from data of 127 years observations at Samoa. He found that spawning of palolo is consistent in several days but inconsistent in other days. There is neither similar study on prediction of palolo swarming nor wawo and nyale swarming. Swarming of these highly cultural-value worms is predicted only by traditional method that unable to satisfy demands of tourism market.

The present study developed a scientifically based method to predict the date of nyale swarming. Constructing such a prediction model requires data on spawning dates on previous years. In the case of nyale worm spawning, there are very few data available. Both traditional community and government do not have record of swarming dates, including date of large and low harvest of nyale. This paper will predict dates of nyale swarming based on only 4 (four) available data and verify the prediction with available data on websites.

\section{MATERIALS AND METHODS}

\section{Hypothesis development}

Previous studies on marine invertebrate showed that spawning patterns of nyale worms are similar to spawning patterns of corals. It has been reported that Polychaete spawned at about the same nights with coral spawning in the Great Barrier Reefs (GBR), Australia (Willis et al. 1985; Babcock et al. 1986; Hutching and Howitt 1988) and in Samoa (Mundy and Green 1999). Coral spawning in GBR usually occurs once a year in October or November or in both months (Harrison et al. 1984; Willis et al. 1985; Babcock et al. 1986). Palolo worms spawning also take place in October and November in Samoa (Caspers 1984). It has also been known that dates of coral and palolo worm spawning are synchronized by lunar cycle (full moon).

Similarities between spawning patterns of corals and polychaete worms suggest that coral spawning prediction method at GBR can be customized to predict polychaete worm spawning at Lombok waters. Cultural leaders of Lombok people (Sasak) testify that spawning date of nyale worms regularly occurs once a year in February and March. Date of spawning is on the twentieth of lunar date in the Sasak or Rowot Calendar. In Lombok, some coral spawning also peaks in February and March (Bachtiar 2001) and the spawning date is strongly related to full moon. Furthermore, coral spawning in Lombok waters is about the same as in Dampier Archipelago, Western Australia (Babcock et al. 1994). These similarities suggest the existence of a particular spawning pattern in nyale worms of Lombok waters.

In the GBR, coral spawning pattern has critical dates related to the full moon of October. Corals had split spawning in October and November, when full moon occurred in $10^{\text {th }}$ and $13^{\text {th }}$ October as happened in 1981 and 1984 respectively (Willis et al. 1985). Soft corals of the GBR also had split spawning in October and November when full moon occurred in $7^{\text {th }}$ October 1987 (Alino et al. 1989). Caspers (1984) observation on palolo worms in Samoa revealed that palolo swarming was consistent when it occurred between $18^{\text {th }}-31^{\text {th }}$ October and $1^{\text {st }}-18^{\text {th }}$ November, but it inconsistent between $8^{\text {th }}-18^{\text {th }}$ October and $18^{\text {th }}-23^{\text {rd }}$ November. He also recorded that palolo worm spawning takes places on the last third quarter of the moon phase, or 6 days after the full moon.

Spawning observations during the last 4 (four) years (2015-2018) revealed that: (i) Spawning of nyale worms take places only in February (2016), only in March (2015, 2018) or in both February and March (2017). (ii) Date of spawning always takes places in the $20^{\text {th }}$ lunar day ( 5 days after the full moon), regardless of the month of spawning. (iii) Time of spawning also consistently start at 03:00 am early in the morning. (iv) There was no spawning in February 2015, when full moon occurred on $4^{\text {th }}$ of February 2015. Neither spawning occurred in February 2018, when full moon appeared on $31^{\text {st }}$ January. (v) Spawning may be distributed or split in two months, February and March. The split spawning took place in 2017, but did not happen in 2015 and 2016.

Based on existing studies on coral spawning and the four years observations, we developed three hypotheses (Figure 1): (i) Spawning will take place 5 days after the full moon of March only, when February full moon occurs in the first quarter (1-6 solar days). (ii) Spawning will occur 5 days after the full moon of both February and March, when the full moon of February arises in the second quarter (7-14 solar days). (iii) Spawning will happen 5 days after the full moon of February only, when February full moon occurs in the second half (15-29 solar days).

These hypotheses need to be verified with existing data to determine its accuracy. In the present study, 100 prediction of spawning dates were generated based on the three hypotheses to see patterns of the swarming (Table 1). The prediction dates are then verified with data of spawning dates in the past (2007-2018). 


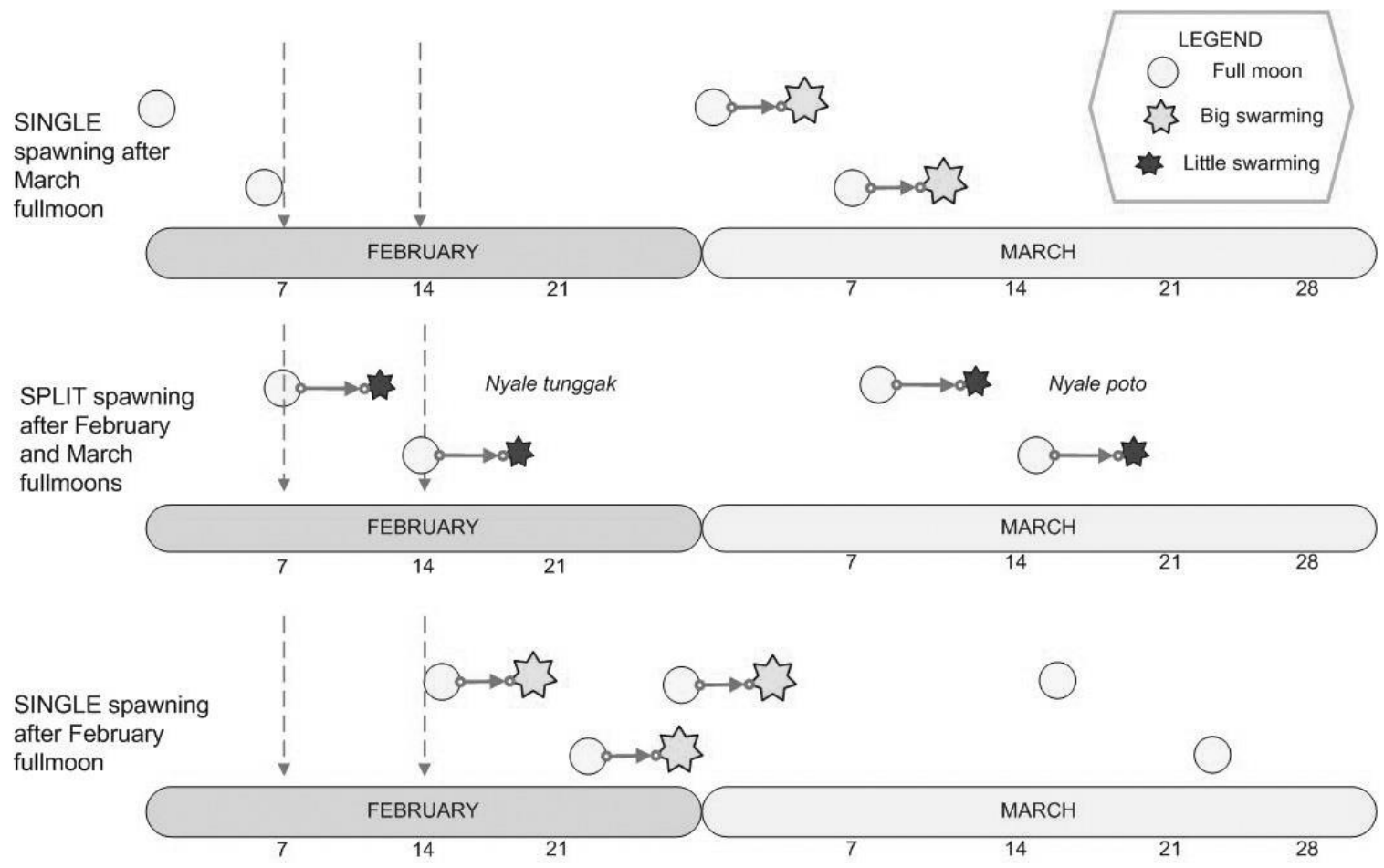

Figure 1. Hypotheses of spawning patterns of nyale worms in southern coast of Lombok Island, Indonesia

\section{Data collection}

Data of full moons in international lunar calendar or Chinese lunar calendar were collected from www.timeanddate.com. Data of full moons on lunar National (Hijri), Bali and Rowot Calendars were collected from printed calendars.

Spawning dates of nyale worms were observed in February and March during the period of 2015-2018. Additional data on nyale worm spawning were collected from social media that was available on the internet. Some people posted their travels on Bau Nyale Festive. Sometimes, they included reports on how much worms were collected. These data are the only available data to verify the hypotheses.

Data of dates of spawning published in online media were selectively used in verification. Online media mostly used data from the government source. They usually produced information on government preparation for the Bau Nyale Festive and the date of the coming festive. Two times $(2015,2017)$ in the last four years, however, dates of spawning issued on government websites were inaccurate. When wrong prediction occurred, online media did not report about this issue, neither did government website. The news about the Bau Nyale Festive in online media, therefore, showed low accuracy.

There were no available data on government offices to verify the hypotheses. Government-produced online information on Bau Nyale Festive, but it is only about dates when the festival will be carried out on a particular year. This data will only be used as supporting data.

\section{RESULTS AND DISCUSSION}

Scientific prediction revealed that during the period of 2000 to 2100 (100 years), months of nyale worms spawning would be distributed unequally in favor to March than February. Spawning frequency in February, March and both months (split spawning) are 58, 68 and 25 respectively (Table 1). These results show some significant differences from existing local knowledge on nyale swarming. It is thought that February is the most common spawning month of nyale worms, but this prediction model shows that nyale swarming is more frequent on March than February.

The scientific prediction also shows that split spawning does not come about every year. This prediction is in contrast with community perception or beliefs from traditional leaders. They claim that nyale swarming always occurs two times a year, in February and March. The first nyale swarming is called nyale tunggak (in February) and the second swarming is called nyale poto (in March). They are also aware that abundance of nyale between the two swarming dates is not the same, sometimes more plentiful on the first swarming in other times it is more copious on the second one. In 2015, 2016, 2017 and 2018, traditional nyale fishers came to Mandalika Beach in both February and March. They only found the split swarming in 2017. 
Table 1. A century spawning prediction generated from Bachtiar hypotheses

\begin{tabular}{|c|c|c|c|c|c|c|c|}
\hline \multirow{2}{*}{ Year } & \multicolumn{2}{|c|}{ Fullmoon } & \multirow{2}{*}{ Predicted swarming date } & \multirow{2}{*}{ Year } & \multicolumn{2}{|c|}{ Fullmoon } & \multirow{2}{*}{ Predicted swarming date } \\
\hline & Feb. & Mar. & & & Feb. & Mar. & \\
\hline 2000 & 20 & 20 & $25 \mathrm{Feb}$ & 2051 & 25 & 27 & 2 Mar. \\
\hline 2001 & 8 & 10 & Split spawning 13 Feb. and 15 Mar. & 2052 & 15 & 15 & 20 Feb. \\
\hline 2002 & 27 & 29 & 4 Mar. & 2053 & 3 & 5 & 10 Mar. \\
\hline 2003 & 17 & 18 & 22 Feb. & 2054 & 22 & 24 & 27 Feb. \\
\hline 2004 & 6 & 7 & 12 Mar. & 2055 & 12 & 13 & Split spawning 17 Feb. and 18 Mar. \\
\hline 2005 & 24 & 26 & 1 Mar. & 2056 & 1 & 2 & 7 Mar. \\
\hline 2006 & 13 & 15 & Split spawning 18 Feb. and 20 Mar. & 2057 & 19 & 21 & 24 Feb. \\
\hline 2007 & 2 & 4 & 9 Mar. & 2058 & 8 & 10 & Split spawning $13 \mathrm{Feb}$. and 15 Mar. \\
\hline 2008 & 21 & 22 & 26 Feb. & 2059 & 27 & 29 & 4 Mar. \\
\hline 2009 & 9 & 11 & Split spawning 15 Feb. and 16 Mar. & 2060 & 16 & 17 & 21 Feb. \\
\hline 2010 & - & 1,30 & 6 Mar. & 2061 & 4 & 5 & 10 Mar. \\
\hline 2011 & 18 & 20 & 23 Feb. & 2062 & 23 & 25 & $28 \mathrm{Feb}$ \\
\hline 2012 & 8 & 8 & Split spawning 13 Feb. and 13 Mar. & 2063 & 13 & 15 & Split spawning: 20 Feb. and 20 Mar. \\
\hline 2013 & 26 & 27 & 3 Mar. & 2064 & 3 & 3 & 8 Mar. \\
\hline 2014 & 15 & 17 & 20 Feb. & 2065 & 21 & 22 & 26 Feb. \\
\hline 2015 & 4 & 6 & 11 Mar. & 2066 & 10 & 12 & Split spawning $15 \mathrm{Feb}$. and 17 Mar. \\
\hline 2016 & 23 & 23 & $28 \mathrm{Feb}$ & 2067 & - & 1,31 & 6 Mar. \\
\hline 2017 & 11 & 12 & Split spawning 15 Feb. and 17 Mar. & 2068 & 18 & 19 & 23 Feb. \\
\hline 2018 & - & 2,31 & 7 Mar. & 2069 & 6 & 8 & 13 Mar. \\
\hline 2019 & 19 & 21 & 24 Feb. & 2070 & 25 & 27 & 2 Mar. \\
\hline 2020 & 9 & 10 & Split spawning 14 Feb. and 15 Mar. & 2071 & 14 & 16 & Split spawning: $19 \mathrm{Feb}$. and $21 \mathrm{Mar}$. \\
\hline 2021 & 27 & 29 & 4 Mar. & 2072 & 4 & 4 & 9 Mar. \\
\hline 2022 & 17 & 18 & 22 Feb. & 2073 & 22 & 24 & 27 Feb. \\
\hline 2023 & 6 & 7 & 12 Mar. & 2074 & 12 & 13 & Split spawning $17 \mathrm{Feb}$. and 18 Mar. \\
\hline 2024 & 24 & 25 & $29 \mathrm{Feb}$ & 2075 & 1 & 3 & 8 Mar. \\
\hline 2025 & 12 & 14 & Split spawning 17 Feb. and 19 Mar. & 2076 & 20 & 21 & 25 Feb. \\
\hline 2026 & 2 & 3 & 8 Mar. & 2077 & 8 & 10 & Split spawning 13 Feb. and 15 Mar. \\
\hline 2027 & 21 & 22 & 26 Feb. & 2078 & 27 & 28 & 4 Mar. \\
\hline 2028 & 10 & 11 & Split spawning 15 Feb. and 16 Mar. & 2079 & 16 & 17 & $31 \mathrm{Feb}$ \\
\hline 2029 & - & 1,30 & 6 Mar. & 2080 & 5 & 6 & 11 Mar. \\
\hline 2030 & 18 & 20 & 23 Feb. & 2081 & 23 & 25 & 28 Feb. \\
\hline 2031 & 7 & 9 & Split spawning 12 Feb. and 14 Mar. & 2082 & 13 & 15 & Split spawning $18 \mathrm{Feb}$. and 20 Mar. \\
\hline 2032 & 26 & 27 & 3 Mar. & 2083 & 3 & 4 & 9 Mar. \\
\hline 2033 & 14 & 16 & Split spawning: $19 \mathrm{Feb}$. and 21 Mar. & 2084 & 22 & 22 & $27 \mathrm{Feb}$ \\
\hline 2034 & 3 & 5 & 10 Mar. & 2085 & 10 & 11 & Split spawning $15 \mathrm{Feb}$. and 16 Mar. \\
\hline 2035 & 22 & 24 & 27 Feb. & 2086 & 28 & 30 & 5 Mar. \\
\hline 2036 & 12 & 12 & Split spawning 17 Feb. and 17 Mar. & 2087 & 17 & 19 & $22 \mathrm{Feb}$ \\
\hline 2037 & - & 2,31 & 7 Mar. & 2088 & 7 & 7 & Split spawning 12 Feb. and 12 Mar. \\
\hline 2038 & 20 & 21 & $25 \mathrm{Feb}$ & 2089 & 25 & 26 & 2 Mar. \\
\hline 2039 & 9 & 11 & Split spawning 14 Feb. and 16 Mar. & 2090 & 14 & 16 & Split spawning: $19 \mathrm{Feb}$. and 21Mar. \\
\hline 2040 & 28 & 28 & 5 Mar. & 2091 & 4 & 5 & 10 Mar. \\
\hline 2041 & 16 & 18 & 21 Feb. & 2092 & 23 & 24 & $28 \mathrm{Feb}$ \\
\hline 2042 & 5 & 7 & 12 Mar. & 2093 & 11 & 13 & Split spawning $16 \mathrm{Feb}$. and 18 Mar. \\
\hline 2043 & 24 & 25 & 1 Mar. & 2094 & - & 2 & 7 Mar. \\
\hline 2044 & 13 & 14 & Split spawning: 18 Feb. and 19 Mar. & 2095 & 19 & 21 & 24 Feb. \\
\hline 2045 & 2 & 3 & 8 Mar. & 2096 & 8 & 9 & Split spawning $13 \mathrm{Feb}$. and 14 Mar. \\
\hline 2046 & 21 & 22 & 26 Feb. & 2097 & 26 & 28 & 3 Mar. \\
\hline 2047 & 10 & 12 & Split spawning 15 Feb. and 17 Mar. & 2098 & 16 & 17 & $21 \mathrm{Feb}$ \\
\hline 2048 & 29 & 30 & 5 Mar. & 2099 & 5 & 7 & 12 Mar. \\
\hline 2049 & 18 & 19 & 23 Feb. & 2100 & 24 & 26 & 29 Feb. \\
\hline 2050 & 7 & 8 & Split spawning 12 Feb. and 15 Mar. & Note: & & ary, $\mathrm{M}$ & r.: March \\
\hline
\end{tabular}

Verification of the accuracy of the prediction shows that the scientific prediction in this study is very accurate. Data from 2007 to 2014 collected from traveler posts on their blogs are almost all in agreement with prediction. There is a disparity, however, between scientific prediction and online-media in 2009 (Table 2). The present scientific prediction reveals that nyale worms had a split spawning on $14^{\text {th }}$ February and $16^{\text {th }}$ March 2009 . Two online-media
(Antara and Lombok Guide) showed that government announcement on date for Bau Nyale was on $15^{\text {th }}$ February. Another online media, Viva, reported the same date and also claimed there were about 30 thousand visitors came to the event. There was no report, however, whether nyale worms really spawned on the predicted morning or not, and no picture showing nyale worms. Such online-media data did not necessarily confirm the date of nyale worm 
spawning. They only reported that Bau Nyale Festival was there. For example, many online-media and blogs reported that government cultural programs for Bau Nyale 2015 would be held in $10^{\text {th }}$ February. The crowd was there but there was no swarming nyale. The failure of government prediction in 2015 did not appear in online media and blogs, but the 2017 failure was reported in one online media only, Liputan6.com.

Swarming observation made between 2015-2018 showed that scientific prediction is very much more accurate than government prediction. In 2015, government prediction missed one month. It was said that Bau Nyale festive would be held on $9^{\text {th }}$ February but nyale swarm actually occurred on $11^{\text {th }}$ March 2015. Furthermore, in 2017, government prediction missed one day. Bau Nyale was said to be done on $17^{\text {th }}$ February but all nyale has already swarmed on $16^{\text {th }}$ February. In the last 5 years, government prediction missed two times but scientific prediction showed its $100 \%$ accuracy.

There is one case that small number of nyale swarmed outside the predicted date. In 2018, scientific prediction was the same as government prediction. It was expected that there would not be any nyale swarming in February since there was no full moon on February 2018 (Chinese calendar). In national Hijri calendar, full moon occurred on $1^{\text {st }}$ February. A few people went to fishing nyale and some of them showed that they caught small number of nyale in social media. The minor nyale swarming was reported happening at Kaliantan Beach, Mandalika Beach and its surroundings (Kuta, Seger and Serinting Beaches). The real swarming took place on $7^{\text {th }}$ March 2018. It was estimated 25 thousand people went fishing nyale and they caught a large number of nyale (nyale tumpah). Such a February minor swarming was also reported in Caspers (1984) and was considered not to be included in swarming pattern.

Table 2. Verification of nyale swarming prediction in Mandalika Beach, Lombok, Indonesia

\begin{tabular}{|c|c|c|c|c|}
\hline Year & $\begin{array}{c}\text { Scientific } \\
\text { prediction }\end{array}$ & Verification & Sources* & Notes \\
\hline 2007 & 9 Mar. & Accurate & $\begin{array}{l}\text { https://lombokleisuretour.com/festival-bau-nyale/ } \\
\text { https://tikets.wordpress.com/2010/09/24/pantai-kuta-lombok-selatan/ } \\
\text { http://hubbulwatoni.blogspot.com/p/blog-page_29.html } \\
\text { http://mahsan-lombok.blogspot.com/2011/04/bau-nyale.html } \\
\text { http://matalombok-tourtravel.blogspot.com/2009/ }\end{array}$ & Single spawning \\
\hline 2008 & 26 Feb. & Accurate & $\begin{array}{l}\text { https://rumah-wisata.blogspot.com/2008/02/lombok-kembali-gelar-tradisi- } \\
\text { bau-nyale.html } \\
\text { https://www.antarafoto.com/korporasi/v1204109661/tradisi-bau-nyale }\end{array}$ & Single spawning \\
\hline 2009 & $\begin{array}{l}14 \text { Feb. and } \\
\text { Mar. }\end{array}$ & $\begin{array}{l}16 \text { GP ( } 15 \text { Feb), no } \\
\text { confirmation }\end{array}$ & $\begin{array}{l}\text { https://www.viva.co.id/berita/nasional/30309-valentine-disambut-bau- } \\
\text { nyale-di-lombok } \\
\text { http://www.thelombokguide.com/issue_31.html\#bau_nyale_2009 } \\
\text { https://mataram.antaranews.com/berita/1072/menyambut-putri-nyale-di- } \\
\text { pantai-selatan-oleh-anwar-maga }\end{array}$ & Split spawning \\
\hline 2010 & 6 Mar. & Accurate & $\begin{array}{l}\text { http://forum.detik.com/festival-bau-nyale-di-kuta-lombok-tgl-5-6-March- } \\
\text { t142858.html } \\
\text { https://www.antarafoto.com/peristiwa/v1267862403/tradisi-bau-nyale }\end{array}$ & Single spawning \\
\hline 2011 & 23 Feb. & Accurate & $\begin{array}{l}\text { https://travel.detik.com/event-wisata/d-1573547/festival-pesta-rakyat-bau- } \\
\text { nyale-2011 http://www.berbagifun.com/2011/03/pesta-bau-nyale-lombok- } \\
\text { part-2.html }\end{array}$ & Single spawning \\
\hline 2012 & $\begin{array}{l}13 \text { Feb. and } \\
\text { Mar. }\end{array}$ & 13 Accurate & $\begin{array}{l}\text { http://www.kemenpar.go.id/asp/detil.asp?c=16\&id=1196 } \\
\text { http://wonderfulnusantaraa.blogspot.com/2017/09/festival-bau-nyale- } \\
\text { 2012-melebur-dalam.html\# } \\
\text { https://news.detik.com/foto-news/1840845/karnaval-jelang-festival-bau- } \\
\text { nyale/1 } \\
\text { http://budi-lombok18.blogspot.com/2012/02/event-bau-nyale-di-pantai- } \\
\text { seger-kuta.html }\end{array}$ & Split spawning \\
\hline 2013 & 3 Mar. & Accurate & $\begin{array}{l}\text { http://www.kemenpar.go.id/asp/detil.asp?c=43\&id=308 } \\
\text { http://www.berbagifun.com/2013/02/bau-nyale-2013-di-lombok- } \\
\text { tengah.html } \\
\text { http://ultimoparadiso.com/keunikan-festival-bau-nyale-angkat-pariwisata- } \\
\text { lombok.html }\end{array}$ & Single spawning \\
\hline 2014 & 20 Feb. & Accurate & $\begin{array}{l}\text { https://www.thelangkahtravel.com/wisata-di-lombok-festival-bau-nyale/ } \\
\text { http://lombok.panduanwisata.id/wisata-sejarah/pesta-adat-bau-nyale-di- } \\
\text { nusa-tenggara-barat/ } \\
\text { http://www.jurnalsulawesi.com/wisatawan-diajak-meriahkan-tradisi-bau/ }\end{array}$ & Single spawning \\
\hline $2015 * *$ & 11 Mar. & Accurate & Present study & Single spawning \\
\hline 2016 & 28 Feb. & Accurate & Present study & Single spawning \\
\hline $\begin{array}{l}2017 \\
* * *\end{array}$ & $\begin{array}{l}16 \text { Feb. and } \\
\text { Mar. }\end{array}$ & 19 Accurate & Present study & Split spawning \\
\hline 2018 & 7 Mar. & Accurate & Present study & Single spawning \\
\hline
\end{tabular}


There were two other mismatches, however, between the scientific prediction and dates of nyale worm spawning published in proceeding and journal articles. In 1992, nyale swarming was reported took place on $23^{\text {rd }}$ February and $23^{\text {rd }}$ March (Jekti et al. 1992). Since February full moon occurred on $18^{\text {th }}$ February 1992, scientific prediction did not show split spawning but single spawning in $23^{\text {rd }}$ February. In addition, nyale swarming in 1993 was reported happened on $13^{\text {th }}$ February (Jekti et al. 1993). This was one day mismatch with the prediction. In 1993, full moons were on $7^{\text {th }}$ February and $8^{\text {th }}$ March, that nyale was expected to have split spawning on $12^{\text {th }}$ February and $13^{\text {th }}$ March. The mismatches in 1992 and 1993 swarming left without any convincing explanation.

There are explanations, however, for government missed predictions in 2015 and 2017. In both years, nyale swarming was in favor to scientific prediction. In 2015, the government missed one month. On the present hypotheses, nyale would never swarm before $12^{\text {th }}$ February. Since February full moon was on $4^{\text {th }}$ February, then nyale would swarm after the March full moon, $11^{\text {th }}$ March. In 2017, government's missed prediction was due to difference in dates of full moon among printed calendars. Hijri (national) and Rowot (Lombok) lunar calendars showed that the full moon occurred on $12^{\text {th }}$ February, therefore they predicted nyale swarming on $17^{\text {th }}$ February. In contrast, Chinese and Balinese lunar calendars indicated the full moon was on $11^{\text {th }}$ February that, according to these calendars, nyale would be swarm on $16^{\text {th }}$ February. The fact was nyale swarmed on $16^{\text {th }}$ February.

Concurrence the date of nyale swarming to Chinese lunar calendar has also happened on 2016 swarming. There were four versions of February full moon among four lunar calendars. Lunar calendars of Balinese, Nasional (Hijri), Chinese and Rowot displayed February full moon on $21^{\text {st }}$, $22^{\text {nd }}, 23^{\text {rd }}$, and $24^{\text {th }}$ respectively. Nyale swarming occurred on $28^{\text {th }}$ February. So far, there are two cases indicating that nyale worms are likely run-through Chinese lunar calendar.

The present study still has two unresolved concerns. Firstly, critical date of February full moons that changes spawning pattern, i.e., 7 and 14 of February (solar calendar), is urgent to be determined its accuracy. These critical dates were constructed with very limited data. Since there are no sufficient available records and nyale reproductive cycle only once a year, we need to wait until 2031 and 2050 (February full moon will be on $7^{\text {th }}$ ) and 2034 and 2071 (February full moon will be on $14^{\text {th }}$ ). Available data on other places may be helpful to understand these critical dates in nyale swarming. Furthermore, this study does not recognize the inconsistency of spawning dates as reported by Caspers (1984). He recorded several dates when palolo swarming occurs inconsistently, i.e., $8^{\text {th }}-18^{\text {th }}$ October and $8^{\text {th }}-23^{\text {rd }}$ November. Since palolo swarming take place 7 (seven) days after the full moon in Samoa (Mundy and Green 1999), the inconsistent swarming dates occurred when October full moon happens on $1^{\text {st }}-11^{\text {th }}$ October. In Lombok, nyale swarming was predictable when February full moon was on $4^{\text {th }}$ February (2015), $11^{\text {th }}$ February (2017) and none on February (2018). Since data on nyale swarming dates are very much less than data on palolo swarming, it did not really show that patterns of nyale swarming do not support Caspers' observation in Samoa.

This study potentially can be used to find out spawning patterns of wawo worms in Ambon and palolo worms in Samoa. Palolo worms in Samoa have a good record of their spawning times. Wawo worms in Ambon, however, might not have records on their spawning, unless there is a missionary recording data as what happened in Samoa. In developing countries, such as Indonesia and Samoa, government staffs are very rare in recording data on natural cycles of animal reproductions as the spawning of nyale worms. When there is no scientist studying the animal, there will not be any data for centuries.

The present scientific prediction can be used to satisfy tourism market demand in promotion. Using this prediction traveler can make an accurate and long-term travel plan when they want to see nyale fishing (Bau Nyale) festival. It should be realized however that the prediction should not dismiss existing traditional sacred meeting to determine date of nyale fishing, the Sangkep Beleq. Since the meeting is part of the cultural protocol in Bau Nyale tradition, the scientific prediction should be apprehended as scientific contribution to strengthening cultural and economic development. Indonesian Ministry of Tourism and Culture should adopt the present study to better promoting Lombok tourism. A century nyale swarming dates predicted in the present study (see Table 1) would be more than sufficient to improve tourism promotion for international travelers.

\section{ACKNOWLEDGEMENTS}

Authors would like to thank Ms. Indah Juanita of Indonesian Tourism Development Corporation (ITDC), who gives a new hobby of watching spawning of nyale worms. Our gratitude are extended to Karnan, Lalu Japa, Didik Santoso, Atas Pracoyo, Eko Prajoko, and Iin Inayat Al Hakim for their supports in discussions and field observations.

\section{REFERENCES}

Alino PM, Coll JC. 1989. Observations of the synchronized mass spawning and post-settlement activity of octocorals on the Great Barrier Reef, Australia: Biological aspects. Bull Mar Sci 45 (3): 697707.

Babcock RC, Willis BL, Simpson CJ. 1994. Mass spawning of corals on a high latitude coral reef. Coral Reefs 13:161-169.

Babcock RC, Bull GD, Harrison PL, Heyward AJ, Oliver JK, Wallace CC, Willis BL. 1986. Synchronous spawnings of 105 scleractinian coral species on the Great Barrier Reef. Mar Biol 90 (3): 379-394.

Bachtiar I. 2001. Reproduction of three scleractinian corals (Acropora cytherea, A. nobilis, Hydnophora rigida) in eastern Lombok Strait, Indonesia. Ilmu Kelautan 21: 18-27.

Brownstein O, Loya Y. 2015. Photoperiod, temperature, and food availability as drivers of the annual reproductive cycle of the sea urchin Echinometra sp. from the Gulf of Aqaba (Red Sea). Coral Reefs 34: 275-289. 
Caspers H. 1984. Spawning periodicity and habitat of the palolo worm Eunice viridis (Polychaeta: Eunicidae) in the Samoan Islands. Mar Biol 79 (3): 229-236

Fong PF. 1993. Lunar control of epitokal swarming in the Polychaete Platynereis bicanaliculata (Baird) from Central California. Bull Mar Sci 52 (3): 911-924.

Harrison PL, Babcock RC, Bull GD, Oliver JK, Wallace CC, Willis BL. 1984. Mass spawning in tropical reef corals. Science 23: 1186-1189.

Hutchings PA, Howitt L. 1988. Swarming of polychaetes on Great Barrier Reef. In: Choat JH, Barnes D, Borowitzka MA, Coll JC, et al. (eds.) Proceedings of the $6^{\text {th }}$ International Coral Reef Symposium. James Cook University, Townsville, 8-12 August 1988.

Jekti DSD, Ramdani A, Suryawati H. 1992. Several ecological aspects of nyale worms. Proceeding of Scientific Seminar on Biological and Sociological Aspects of Nyale. Universitas Islam Al Azhar, Mataram, 30 April 1992. [Indonesian].

Jekti DSD, Yulianti E, Suryawati H, Maswan M, Kastoro W. 1993. Polychaete diversity in Lombok Island and Bau nyale tradition. Jurnal
Ilmu-Ilmu Perairan dan Perikanan Indonesia 1 (1): 21-32. [Indonesian]

Mundy C, Green A. 1999. Spawning Observations of Corals and Other Invertebrates in American Samoa. Report prepared for Department of Marine and Wildlife Resources, American Samoa Government, 1-12.

Olive PJW. 1980. Control of the reproductive cycle in female Eulala viridis (Polychaeta: Phyllodocidae). J Mar Biol Ass UK 61: 941-958.

Olive PJW. 1995. Annual breeding cycles in marine invertebrates and environmental temperature: Probing the proximate and ultimate causes of reproductive synchrony. J Therm Biol 20 (1/2): 79-90.

Pamungkas J. 2015. Species richness and macronutrient content of wawo worms (Polychaeta, Annelida) from Ambonese waters, Maluku, Indonesia. Biodiv Data J 3: e4251. DOI: 10.3897/bdj.3.e4251.

Willis BL, Babcock RC, Harrison PL, Oliver JK, Wallace CC. 1985. Patterns in the mass spawning of corals on the Great Barrier Reef from 1981 to 1984. In: Delesalle B, Galzin R, Salvat B. (eds.) Proceeding $5^{\text {th }}$ International Coral Reef Congress, Tahiti, 27 May -1 June 1985. 